logos_i_ethos_2016_(43)_numer_specjalny_2, s. 49-64

DOI: http://dx.doi.org/10.15633/lie.1959

\title{
Тереза Оболевич
}

\section{Два философа: Семен Франк о Петре Чаадаеве'}

В последнее время наблюдается стремительный рост интереса к творчеству С. Л. Франка, а особым показателем является немалое число публикаций его ранее с. Тереза Оболевич - профессор Папского университета Иоанна Павла II в Кракове, член Центра междисциплинарных исследований им. Коперника. Email: tereza. obolevich@upjp2.edu.pl. неизданных архивных текстов. В настоящем номере журнала впервые публикуются два конспекта докладов С. Л. Франка о П. Я. Чаадаеве, один из которых изначально был написан по-русски, а другой - по-немецки (приводится русский перевод). Стоит осветить обстоятельства появления данных текстов, оригиналы которых хранятся в Бахметьевском архиве Колумбийского университета (Нью-Йорк).

Текст, озаглавленный «Чаадаев» написан от руки на двух страницах (чернилами и частично карандашом). На картонной папке, содержащей рукопись (бокс 11), имеется следующая надпись:

«Frank, Semen Liudvigovich.

Chaadaev.

n.p., [1931]

a.ms., 3 p<ages $>$. (lecture)».

1 Статья подготовлена в рамках реализации гранта «Наука, философия и политика в русской религиозной мысли», признанного Национальным центром науки Республики Польша, UMO-2014/15/B/HS1/01620. Выражаю глубокую признательность проф. Геннадию Аляеву (Полтава) за внимательное прочтение и редакторскую правку. 
Однако третий лист содержит конспект лекции о И. В. Киреевском. Второй, публикуемый в журнале, текст (из 12 бокса) представляет собой фрагмент немецкого лекционного курса философа. Известно, что С. Л. Франк прочел доклад о Чаадаеве (по-немецки) 28 октября 1930 г. в Берлинском университете (улица Hörsaal 29) под заглавием «Denkerdes 19. Jahrhunderts. EsterVortrag: Čaadaev» ${ }^{2}$. Франк был лектором истории русской мысли Института славистики Берлинского университета в 1930-1933 гг. по инициативе немецкого филолога, уроженца Санкт-Петербурга Макса Фасмера ${ }^{3}$. В письме швейцарскому философу и богослову Фрицу Либу Франк сообщал:

Через посредничество Фасмера я получил от министерства назначение: читать в рамках Института славистики лекции из области ист<ории> идей$<$ ных> течений в России. Оплата скверная - 600 м<арок> за семестр, но мне после длительного перерыва доставляет удовольствие снова вести настоящий курс со студентами ${ }^{4}$.

В одном из очередных писем Франк делился с Ф. Либом:

Вчера я узнал, что Фасмер получил телеграфный запрос декана филос<офского> факультета в Бонне о кандидатах на русский лекторат и русс<кую> историю (где меня в списке кандидатов не было) и по телеграфу рекомендовал на это место меня. [...] При сем посылаю Вам данные о моем curriculum vitae и сочинениях. [...] Прошу Вас, держите меня о дальнейшем в курсе дела. Здесь в министерстве культуры у Рихтера за меня, по-видимому, будет ходатайствовать Фасмер (а также Серинг). Мой доклад о русском и немецком духовном 1999 , c. 417.

2 Chronik russischen Lebens in Deutschland 1918-1941, Hrsg. K. Schlögel и др., Berlin

3 См. В. В. Янцен, Об иррациональном в истории. Биографические заметки к переписке С. Л. Франка и Д. И. Чижевского (1932-1937, 1947 гг.), в: Русский Берлин 1920-1945, ред. М. А. Васильева, Л. С. Флейшман, Москва 2006, с. 310-311.

4 Письмо С. Л. Франка к Ф. Либу от 22 января 1931 г. (В. Янцен, Письма русских мыслителей в архиве Фрииа Либа, в: Исследования по истории русской мысли. Ежегодник за 2001-2002 год, ред. М. А. Колеров, Москва 2002, с. 477). 
типе знает также философ Ханс Дриш из Лейпцига, очень ценящий мои работы (Leipzig, Zollnerstr. 1). Здесь в Берлине меня рекомендовал бы и Штелин 5 .

Однако место в Бонне Франку получить не удалось. Впоследствии в своей автобиографической заметке Франк уточнил:

с 1930 г. - по поручению прусского министерства for Science and Art - читал в берлинском университете лекции по русской литературе, философии и духовной культуре. Это поручение (Lehrauftrag) было отнято новым министерством в апреле 1933 г., очевидно, в силу неарийского происхождения ${ }^{6}$.

Кроме того, Франк регулярно выступал перед слушателями Русского научного института и Русского студенческого христианского движения (РСХД) в Берлине, часто ездил с докладами по Германии и европейским странам ${ }^{7}$ (как следует из автобиографии Голландии, Швейцарии, Италии, Польши, Чехословакии, Сербии, Литве, Латвии и Эстонии).

Цикл из трех лекций, посвященный русской философии, начался еще летом 1930 года, а осенью Франк продолжил его в виде шести лекций на тему русских мыслителей XIX века. Благодаря хронике газеты кадетского направления «Руль», издававшейся русскими эмигрантами в Берлине в 20-30-е годы прошлого столетия, удалось воспроизвести последовательность докладов Франка:

- 3 июня 1930 г. - «Grundzüge des russischengeistigen Lebens im XIX. Jahrhundert (1 Vortrag)» («Основы российской интеллектуальной жизни в XIX веке (1 лекция)»);

- 17 июня 1930 г. - вторая лекция (без указания названия);

- 24 июня 1930 г. - третья лекция (также без указания названия);

5 Письмо С. Л. Франка к Ф. Либу от 19 мая 1930 г. (В. Янцен, Письма русских мысслителей в архиве Фрииа Либа, ор. cit., с. 503-504).

6 С. Франк, Автобиография, публ. Т. Оболевич, в: Історія філософії у вітчизняній духовній культурі, ред. Г. Е. Аляев и др., Полтава 2016, с. 515-516.

Ср. А. А. Гапоненков, Две парадигмы в контексте русской мысли, «Общая тетрадь» 58 (2012) 1, с. 1. 
- 28 октября 1930 г. «Denker des 19. Jahrhunderts. Erste Vortrag: Čaadaev» («Мыслители XIX века. Первая лекция: Чаадаев»);

- 4 ноября 1930 г. - «Russische Denker des 19. Jahrhunderts. Zweiter Vortrag: Die Slawophilen. Kireevskij» («Русские мыслители XIX века. Вторая лекция: Славянофилы. Киреевский»);

- 11 ноября 1930 г. - «Russische Denker des 19. Jahrhunderts. Dritter Vortrag: Aleksandr Gerzen» («Русские мыслители XIX века. Третья лекция: Александр Герцен»);

- 18 ноября 1930 г. - «Russische Denker des 19. Jahrhunderts. Vierter Vortrag: Dostoevskij» («Русские мыслители XIX века. Четвертая лекция: Достоевский»);

- 25 ноября 1930 г. - «Russische Denker des 19. Jahrhunderts. Fünfter Vortrag: Konstantin Leont’ev» («Русские мыслители XIX века. Пятая лекция: Константин Леонтьев»);

- 2 декабря 1930 г. - «Russische Denker des 19. Jahrhunderts. Sechster Vortrag: Vladimir Solov’ev» («Русские мыслители XIX века. Шестая лекция: Владимир Соловьев») .

Вполне вероятно, что текст из 11 коробки, озаглавленный Чаадаев, представляет собой конспект русской версии лекциии из немецкого курса Russische Denker или же черновик планируемой им статьи. В 1931 году философ сообщал Фрицу Либу:

Если статья о Рильке Вам не подойдет (или если Вы в состоянии устроить ее где-нибудь в другом месте более прибыльно), то я мог бы написать для «Or $<$ ient $>\mathrm{u}<\mathrm{nd}>\mathrm{Occ}<\mathrm{ident}>$ » статью о Петре Чаадаеве по случаю 75-летия со дня его смерти. Таким образом, я ожидаю от Вас известий и либо сразу пошлю Вам статью о Рильке, либо начну писать для Вас статью о Чаадаеве?.

8 Chronik russischen Lebens in Deutschland 1918-1941, op. cit., c. 404, 406-407, 417419, 421-423.

9 Письмо С. Л. Франка к Ф. Либу от 4 апреля 1931 г. (В. Янцен, Писъма русских мыслителей в архиве Фрииа Либа, ор. cit., с. 491). 
Можно предположить, что Франк намеревался написать статью о Чаадаеве на основе своей берлинской лекции 1930 года. Вполне возможно также, что текст из 11 бокса, озаглавленный «Чаадаев», представляет собой черновик планируемой статьи - об этом косвенно свидетельствует упоминание в этой работе о 75-летии со дня смерти русского философа, которое отмечалось именно в 1931 году, том самом, в котором Франк писал редактору журнала «Orient und Occident» Ф. Либу. Однако в вышеуказанном издании статья Франка о Чаадаеве не выходила.

Франк в своем творчестве немало места уделял исследованиям в области русской религиозной философии - той традиции, в которой он вырос и которой многим обязан, даже если, по его признанию в работе Непостижимое. Онтологическое введение в философию религии, за «единственного учителя философии» он считал Николая Кузанского ${ }^{10}$. Достаточно сказать, что С. Л. Франк редактировал сборники Из истории русской философской мьсли кониа XIX и начала XX века и A Solovyov Anthology, опубликовал такие статьи, как Сущность и ведущие мотивы русской философии, Русская философия кониа ХІХ и начала ХХ века, Русская философия последних пятнади,ати лет и др., а также ряд рецензий, воспоминаний и других работ (в том числе, на немецком и английском языках) на тему русской мысли в целом и ее отдельных представителей. В 40-е годы ХХ века прочел цикл бесед о В. С. Соловьеве на радиостанции Би-би-си, а в 1950 г. посвятил ему свою последнюю статью ${ }^{11}$. И это неудивительно, поскольку Соловьев был «поддержкой и камертоном» собственных воззрений Франка ${ }^{12}$.

10 Ср. С. Л. Франк, Непостижимое. Онтологическое введение в философию религии, в: С. Л. Франк, Сочинения, Москва 1990, с. 184.

11 С. Л. Франк, Духовное наследие Владимира Соловьева, «Вестник Русского Студенческого Христианского Движения» (1950) 4-5, с. 2-10.

12 Ср. В. Кантор, Философия В. С. Соловьева как камертон миропонимания С. Л. Франка, в: «Самый выдающийся русский философ»: Философия религии и политики С. Л. Франка. Сборник научных статей, ред. К. М. Антонов, Москва 2015, с. 135. 
Как отмечает Г. Аляев, «буквально накануне появления первых немецких статей С. Франка вышел в немецком переводе очерк истории русской философии Э. Радлова», которая, согласно Д. Чижевскому, являлась «первой попыткой ознакомить широкие круги немецких (да и только ли немецких) читателей с развитием русской мысли», однако попыткой «далеко не удовлетворительной», поскольку далекой от ясности «в вопросе об “относительной величине” отдельных мыслителей» ${ }^{13}$. Стоит также упомянуть об издании работы вышеуказанного Фрица Либа (имевшего широкие контакты с русскими мыслителями) под заглавием Западно-европейская духовная жизнь в оценке русской религиозной философии (1929 г.), в которой, как отметил Франк в своей рецензии (написанной по требованию редактора «Theologische Blatter» в Йене Карла Л. Шмидта ${ }^{14}$ ), рассматривалась и философия Чаадаева ${ }^{15}$. В свою очередь, немецкий перевод избранных произведений Чаадаева был выпущен Ильей Гурвичем еще в 1921 году ${ }^{16}$. Не подлежит сомнению, что как немецкие публикации Франка, так и его лекции также во многом способствовали пробуждению интереса к русской мысли (в том числе, к творчеству Чаадаева) в Германии и других европейских странах, причем это был взгляд не «снаружи», а «изнутри» русской духовной и интеллектуальной традиции.

П. Я. Чаадаев привлек внимание С. Л. Франка как один из первых оригинальных русских мыслителей, задавших вопросы, которые не потеряли своей актуальности и в XX веке. В раннем Дневнике

13 Г. Е. Аляев, С. Франк как историк русской философии, «Соловьевские исследования» 39 (2013) 3, с. 84.

14 См. Письмо С. Л. Франка к Ф. Либу от 10 августа 1929 г. (В. Янцен, Письма русских мьслителей в архиве Фрица Либа, ор. сіt., с. 454).

15 См. С. Франк, [рец.] Fritz Lieb. Das westeuropäische Geistesleben im Urteile russischer Religionsphilosophie. Sammlung gemeinverständlicher Vortäge. 1929. J. С. B. Mohr, «Руль», 25 сентября 1929 , с. 5.

16 P. J. Tschaadajew, Schriften und Briefe, Übersetzt und eingeleitet von E. Hurwicz, D. Masken, München 1921. См. Н. Плотников, К вопросу об «актуализации» веховской филоcoфии: сборник Russlands politische Seele, в: Исследования по истории русской мысли. Ежегодник за 1997 год, ред. М. А. Колеров, Санкт-Петербург 1997, с. 75. 
Франка можно найти свидетельство о знакомстве с творчеством «басманного философа». В частности, 18 марта 1902 г. он написал о встрече «с Александром Александровичем Бакуниным, последним живым братом М. А. Бакунина, стариком 81 года», который «знал Белинского, Герцена, Чаадаева» ${ }^{17}$. В том же году в переломной работе Фр. Ницие и этика «любви кдальнему» Франк отмечал, что Чаадаев предвосхитил ницшеанскую оппозицию между двумя типами патриотизма: любовью к отечеству «ближнему» и любовью к отечеству будущему, т.е. «дальнему»; противопоставляя «патриотизм самоеда» «патриотизму англичанина» ${ }^{18}$. Имя Чаадаева как великого философа, несмотря на «парадоксальность» и «субъективные детали», составляющие содержание его мыслей ${ }^{19}$, встречается и в Очерках философии культуры (1905 г.). Этот список можно продолжить. Нельзя обойти вниманием и тот факт, что Франк получил издание произведений Чаадаева ${ }^{20}$ от самого М. О. Гершензона, опубликовавшего основные, известные на тот момент, работы московского философа. В письме к нему Франк сообщал:

Спасибо Вам за роскошный подарок - сочинения Чаадаева. Издание превосходное, каких у нас мало; Ваша эрудиция внушает мне глубочайшее почтение и свидетельствует, что Ваша нелюбовь к чистому знанию не мешает Вам быть настоящим ученым, кое-что у Чаадаева оказалось мне прямо нужным для моей работы: отрывок о времени и вечности блестяще выражает одну из основных мыслей моей работы и, может быть, я возьму его эпиграфом к ней ${ }^{21}$.

17 С. Л. Франк, Дневник, публ. Е. П. Никитиной, коммент. А. А. Гапоненкова, в: С. Л. Франк, Саратовский текст, Саратов 2006, с. 70.

18 С. Л. Франк, Фр. Ницие и этика «любви кдальнему», в: С. Л. Франк, Сочинения, op. cit., c. 15.

19 С. Л. Франк, Очерки философии культуры, в: С. Л. Франк, Непрочитанное... Статьи, письма, воспоминания, Москва 2001, с. 40.

20 П. Я. Чаадаев, Сочинения и письма, ред. М. Гершензон, т. 1, Москва 1913.

21 Письмо С. Л. Франка к М. О. Гершензону от 6 апреля 1913 г. (С. Л. Франк, Из пuсем М. О. Гершензону, «De visu» 15 (1994) 3-4, c. 25). 
Цитат из сочинений Чаадаева в Предмете знания, над которым в то время работал Франк, мы не находим. Зато несколько лет спустя, в письме, посланном из Саратова во время своего деканства в местном университете, Франк предлагал Гершензону следующее:

При здешней организации кооперативов («Союз потребит<ельских> обществ Саратовского края») имеется большое и материально хорошо обеспеченное издательство, которое теперь приступает к изданию серии избранных произведений «Классиков политической мысли». Редакцией этого издания заведует проф<ессор> Юровский (экономист, б<ывший > сотрудн<ик $>$ «Рсск <их > Ведомостей») и я. Каждая книжка размером в 12-15 листов, должна содержать избранные произведения (одно или несколько) данного мыслителя и вступительную статью, листа в 2, характеризующую этого мыслителя. Не согласились ли бы Вы принять участие в этом предприятии, обработав для него Чаадаева? Вам было бы совсем нетрудно этого сделать: дать нам право перепечатать теперь, скажем, «Философ<ические> письма» и «Апологию сумасшедшего» и дать нам экстракт в 2 листа из вашей книги о Чаадаеве. Материальн<ые> условия следующие: 1000 руб. с листа оригинальной статьи, и 200 руб. за лист подготовленного к печати текста русского автора, значит за всю книжку 2000+2=2 1/2 т.=4=4 1/2 тыс. рублей. Гонорар уплачивается полностью немедленно по получении рукописи, совершенно независимо от срока напечатания книжки ${ }^{22}$.

\section{После отказа Гершензона переиздать книгу Франк писал:}

Все мы здесь, и редактор, и издатель, скорбим о Вашем отказе и находим его основания недостаточными. Соображения наши следующие: 1) книжный голод так велик, что ни одна книга ни с какой другой не конкурирует, все имеет сбыт, 2) издания нашего «Крайсоюза» (Союза потреб<ительских> обществ Сарат<овского> края) будут распространяться почти всецело все же лишь в волжском районе и по деревням - и потому уже не будут конкурировать с столичным изданием 3) тип изданий - нашего и Ваших книг - настолько

22 Письмо С. Л. Франка к М. О. Гершензону от 21 марта 1919 г. (С. Л. Франк, Из писем М. О. Гершензону, с. 30). 
разнороден, что и поэтому они не конкурируются. Словом, Ваше решение нашим здешним экономистам - и теоретикам и практикам - кажется похожим на решение человека, который в настоящее время боялся бы продавать, напр<имер>, молоко, на том основании, что оно будет конкурировать с имеющимся у него запасом масла. Если бы Вы выпустили Вашего Чаадаева не в двух, а в десяти разных изданиях в разных городах и государствах Р.С.Ф.С.Р., то и тогда бы они все разошлись, и во всяком случае не соперничали бы одно с другим. Не пересмотрите ли Вы еще Вашего решения? ${ }^{23}$

И хотя проекту издания сочинений Чаадаева (под редакцией Гершензона) в Саратове не дано было осуществиться, участие Франка в данном вопросе красноречиво показывает, что его интерес к Чаадаеву не был маргинальным, «по поводу» или «в связи» с другими русскими мыслителями, а имел самостоятельную ценность и значимость. Выписки из книги М. Гершензона Чаадаев. Жизнь и мышление (Москва 1908 г.) содержатся в черновых записях Франка, хранящихся в 15 боксе его фонда в Бахметьевском архиве $^{24}$. Стоит добавить, что в 1930 г. - в том самом, в котором Франк читал лекции в Берлине, в известнейшем журнале «Kant-Studien» вышла его рецензия на опубликованную в 1927 г. книгу приватдоцента Кенигсбергского университета Мартина Винклера Peter Jacovlevič Čaadaev ${ }^{25}$.

Необходимо отметить, что «мода» на «басманного философа» вновь возникла только во второй половине 30-х гг. после публикации в Советской России пяти ранее неизвестных (также Франку) писем русского мыслителя. К тому же,

23 Письмо С. Л. Франка к М. О. Гершензону от 7 мая 1919 г. (С. Л. Франк, Из писем М. О. Гершензону, с. 31).

24 См. С. Франк, <Тетрадь с выписками - отчасти из немецких книг. Литература nо истории мысли>, S. L. Frank Papers, Box 15, Bakhmeteff Archive, Rare Book and Manuscript Library, Columbia University.

25 S. Frank, [Рецензия на:] Winkler Martin. Peter Jacovlevič Čaadaev, «Kant-Studien» 35 (1930) 2/3, с. 388-389. Благодарю за эти сведения Геннадия Аляева. 
этот интерес отчасти наложился на те споры, которые вели в эмиграции русские философы и богословы по поводу софиологического учения С. Н. Булгакова, давшего в своем религиозно-философском учении, как когда-то и П. Я. Чаадаев, своеобразный анализ произошедших культурных трансформаций. [...] Публикация в 1935 г. Д. И. Шаховским считавшихся несохранившимися пяти из восьми чаадаевских писем вызвала ряд публикаций в русской эмигрантской печати. [...] Несмотря на разницу оценок, все мыслители-эмигранты, обращавшиеся к идеям П. Я. Чаадаева, исходили из убеждения, что взгляды П. Я. Чаадаева и он сам до сих пор понимались неадекватно и пришло время акцентировать, что же на самом деле хотел сказать П. Я. Чаадаев и кем он был ${ }^{26}$.

Именно тогда появились известнейшие работы Е. В. Спекторского (К характеристике П. Я. Чаадаева), Б. Зайцева (Проблема Чаадаева), Н. И. Ульянова (Басманный философ); о П. Я. Чаадаеве писали также о. Г. Флоровский в Путях русского богословия, Н. А. Бердяев в Русской идее и В. В. Зеньковский в первом томе Истории русской философии ${ }^{27}$. О последней книге эмигрантский историк и богослов Игорь Смолич (1898-1970) сообщал Франку за полгода до его смерти:

Интересна глава о Чаадаеве, которая написана уже на основании в самое последнее время (1935 г.) опубликованных писем последнего, бывших до сего времени неизвестными. По ним Чаадаев представляется в совершенно новом свете - совсем не ненавистник или отрицатель России, как было принято раньше его штамповать ${ }^{28}$.

Лекция С. Л. Франка появилась не столько на волне вновь возникшего в 30-е годы прошлого века интереса к Чаадаеву, сколько

26 А. В. Прохоренко, Очерки по истории и философии культуры русского зарубежья, Санкт-Петербург 2010, с. 147.

27 См. А. В. Прохоренко, Очерки по истории и философии культуры русского зарубежья, ор. cit., с. 147.

28 Письмо И. Смолича к С. Л. Франку от 24 июня 1950 года, S. L. Frank Papers, Box 8, Bakhmeteff Archive, Rare Book and Manuscript Library, Columbia University. 
в связи с его стремлением понять и представить своим немецким слушателям сущность русской философии и то место, которое занимает в ней автор Философических писем. Франк указывает в своем докладе на основные вехи жизни и творчества Чаадаева, его драматическую судьбу и восприятие современниками - А. С. Пушкиным ${ }^{29}$ и А. И. Герценом, а также на социальную направленность его мысли $^{30}$. Франку «удавались емкие, яркие и меткие характеристики, буквально в нескольких словах отражающие не только духовный облик того или иного мыслителя, но и его роль в культурной жизни российского общества, а порой - и мировой философской мысли» ${ }^{31}$. Особую ценность представляют его рассуждения о Чаадаеве как о первом русском консерваторе - «не в смысле желания возврата назад, а в понимании значения традииии в культурн<ом > развитии» и его «творческом христианстве», выходящим за рамки «узкого конфессионализма» ${ }^{32}$.

Такая позиция была близка и самому Франку. Он также совмещал в себе русский дух и европейский стиль философствования, пресекая

29 Тема отношений Пушкина с Чаадаевым развита в Этюдах о Пушкине (см. С. Л. Франк, Религиозность Пушкина, в: С. Л. Франк, Этюды о Пушкине, Paris 1987, с. 12, 16; С. Л. Франк, Пушкин как политический мыслитель, в: С. Л. Франк, Этюды о Пушкине, ор. cit., с. 32-33, 44-45, 53-54; С. Л. Франк, О задачах познания Пушкина, в: С. Л. Франк, Этюды о Пушкине, ор. сіt., с. 64; С. Л. Франк, Пушкин об отношениях между Россией и Европой, в: С. Л. Франк, Этюды о Пушкине, ор. сіt., с. 94-96; С. Л. Франк, Светлая печаль, в: С. Л. Франк, Этюды о Пушкине, ор. сіt., с. 98, 102-107, 120), а также в написанной по-немецки статье Духовный мир Пушкина.

30 О социальном характере творчества Чаадаева Франк писал также в конспекте лекции «Два течения русской мысли» (S. L. Frank Papers, Box 11, Bakhmeteff Archive, Rare Book and Manuscript Library, Columbia University) и антологии Из истории русской философской мысли кония ХІХ и начала ХХ века (С. Л. Франк, Введение, в: Из истории русской философской мысли кониа ХІХ и начала ХХ века. Антология, ред. С. Франк, Washington-New York 1965, с. 8); см. также А. А. Гапоненков, Проблемы России и Европь в творческом наследии С. Л. Франка, в: Идейное наследие С. Л. Франка в контексте современной европейской культуры, ред. В. Порус, Москва 2009, с. 261.

31 И. Ю. Куляскина, С. Л. Франк: размышления о русской философии, «Вестник Амурского государственного университета. Серия Гуманитарные науки» 68 (2015) 2, с. 23.

32 А. Гапоненков, Лекция Семена Франка о Петре Чаадаеве, «Logos i Ethos» (2016) 43, c. 32 . 
границы чисто национального или конфессионального мышления. Сам Франк «называл себя “христианским универсалистом” или, пользуясь характерным для русской религиозно-философской эмиграции выражением - «надконфессиональным христианином"» ${ }^{33}$. Как верно отметил русско-еврейский писатель Юлий Марголин (1990-1971) в письме к вдове Франка Татьяне Сергеевне, «по отношению к мыслителям такого рода, как С. Л. Франк, никакой национализм - ни узкий, ни “широкий” - конечно неуместен» ${ }^{34}$.

Эта перспектива нашла отражение в публикациях и лекциях Франка, посвященных русской мысли. Их отличительной чертой является

утверждение ее принципиального единства, или родства, или совместимости с философией западноевропейской. Прояснение для западного читателя особенностей русской философской мысли, русского мировоззрения ведётся не в контексте их оправдания и освящения, обратной стороной которого являлось бы низвержение и осуждение западной философии. Цель С. Франка обосновать своеобразие и в то же время универсальную значимость русской философии ${ }^{35}$.

Стоит добавить, что о Чаадаеве и его «западничестве» Франк упоминал в своей статье, написанной несколькими годами ранее для американского читателя и опубликованной во влиятельном журнале «The Monist»" ${ }^{36}$, а в работе Сущность и ведущие мотивы русской философии он отмечал «пессимистическое отрицание русской истории Чаадаевым, который заметил в ней отсутствие разумного религиозного воспитания и традиции, образующих основы

33 В. К. Кантор, Жизнь и судьба С. Л. Франка, в: Идейное наследие С. Л. Франка в контексте современной европейской культурьь, ред. В. Порус, ор. cit., с. 13.

34 Письмо Ю. Марголина к Т. С. Франк от 15 апреля 1965 г., S. L. Frank Papers, Box 9, Bakhmeteff Archive, Rare Book and Manuscript Library, Columbia University.

35 Г. Е. Аляев, С. Франк как историк русской философии, ор. cit., с. 96.

36 Cм. S. Frank, Contemporary Russian Philosophy, «The Monist»37 (1927) 1, p. 1. 
общественной и государственной жизни Европы» ${ }^{37}$. В то же время Франк выражал убеждение, что Чаадаев, «который в холодных как лед мыслях, предложил результаты своей угрюмо-страстной религиозно-нравственной оценки жизни» ${ }^{38}$, не был философом в строгом, западном смысле слова, поскольку не построил универсальной философской системы. Между тем это нисколько не умаляет его значения. Подобно Н. Гоголю, Л. Толстому и другим авторам, он принес «ряд глубоких интуиций, предложив их в очерковой, подчас сырой форме, не обработав ее понятийно-систематически», однако имея ориентацию на «чистое, незаинтересованное понимание мира и жизни» ${ }^{39}$. Не стоит добавлять, что понимание, не отождествляясь с понятием, превосходит его в своем наиболее глубинном, экзистенциальном смысле... Словом, Франк считал Чаадаева одним из наиболее выдающихся представителей не «школьно-систематического», а религиозно-мировоззренческого типа русской мысли ${ }^{40}$.

В вышеуказанном эссе Фр. Ницие и этика «любви к дальнему», а также немецком курсе лекций по русской философии, Франк приводил следующие слова Чаадаева из Апологии сумасшедшего:

Любовь к отечеству вещь очень хорошая, но есть и нечто повыше ее: любовь к истине... Дорога на небо ведет не через любовь к отечеству, а через любовь к истине ${ }^{41}$.

Любовь к истине и отечеству характеризовала и самого Франка. Это был высший комплимент, который философ высказал в письме

37 С. Л. Франк, Сущность и ведущие мотивы русской философии, в: С. Л. Франк, Русское мировоззрение,Санкт-Петербург 1996, с. 154.

38 См. С. Л. Франк, Русская философия, ее характерная особенность и задача, в: С. Л. Франк, Русское мировоззрение, ор. сіt., с. 206.

39 С. Л. Франк, Русская философия, ее характерная особенность и задача, ор. cit., c. 206 .

40 Г. Е. Аляев, С. Франк как историк русской философии, ор. сit., с. 89.

41 С. Л. Франк, Фр. Ницие и этика «любви к дальнему», ор. сit., с. 42. 
к Георгию Федотову, сравнивая его с Чаадаевым как одним из «подлинно честных, нравственно трезвых, независимо мыслящих русских умов», «знающих, что единственный путь спасения лежит через любовь к истине, как бы горька она ни была» ${ }^{42}$. Эти черты и определяли франковский идеал философа как «любомудра», выражая не столько любовь к «отвлеченным началам» и абстрактным рассуждениям, сколько любовь к живой истине и ее неустанный поиск.

\section{Библиография}

Аляев Г. Е., Две парадигмы в контексте философии, «Соловьевские исследования» 39 (2013) 3, с. 78-99.

Гапоненков А. А., Две парадигмы в контексте русской мысли, «Общая тетрадь» 58 (2012) 1, c. 115-126.

Гапоненков А. А., Проблемы России и Европы в творческом наследии С. Л. Франка, в: Идейное наследие С. Л. Франка в контексте современной европейской культуры, ред. В. Порус, Москва 2009, с. 258-265.

Кантор В., Философия В. С. Соловьева как камертон миропонимания С. Л. Франка, в: «Самый выдающийся русский философ»: Философия религии и политики С. Л. Франка. Сборник научных статей, ред. К. М. Антонов, Москва 2015, c. 131-143.

Кантор В. К., Жизнь и судьба С. Л. Франка, в: Идейное наследие С. Л. Франка в контексте современной европейской культуры, ред. В. Порус, Москва 2009, c. 1-14.

Куляскина И. Ю., С. Л. Франк: размышления о русской философии, «Вестник Амурского государственного университета. Серия Гуманитарные науки» 68 (2015) 2, c. 22-30.

Марголин Ю., Письмо к Т. С. Франк от 15 апреля 1965 г., S. L. Frank Papers, Box 9 , Bakhmeteff Archive, Rare Book and Manuscript Library, Columbia University.

42 Письмо С. Л. Франка к Г. Федотову от 27 июня 1949 г., публ. В. К. Кантора, «Вопросы философии» (2006) 3, с. 141. 
Плотников Н., К вопросу об «актуализации» веховской философии: сборник Russlands politische Seele, в: Исследования по истории русской мысли. Ежегодник за 1997 год, ред. М. А. Колеров, Санкт-Петерург 1997, с. 69-93.

Прохоренко А. В., Очерки по истории и философии культуры русского зарубежья, Санкт-Петербург 2010.

Смолич И., Письмо к С. Л. Франку от 24 июня 1950 года, S. L. Frank Papers, Box 8, Bakhmeteff Archive, Rare Book and Manuscript Library, Columbia University. Франк С., [рец.] Fritz Lieb. Das westeuropäische Geistesleben im Urteile russischer Religionsphilosophie. Sammlung gemeinverständlicher Vortäge. 1929. J. C. B. Mohr, «Руль», 25 сентября 1929, с. 5 .

Франк С., Автобиография, публ. Т. Оболевич, в: Історія філособї̈ в вітчизняній духовній культурі, ред. Г. Е. Аляев и др., Полтава 2016, с. 515-516.

Франк С., Два течения русской мысли, S. L. Frank Papers, Box 11, Bakhmeteff Archive, Rare Book and Manuscript Library, Columbia University.

Франк С. Л., Введение, в: Из истории русской философской мысли конца ХІХ и начала ХХ века. Антология, ред. С. Франк, Washington-New York 1965, c. 5-17. Франк С. Л., Дневник, публ. Е. П. Никитиной, коммент. А. А. Гапоненкова, в: С. Л. Франк, Саратовский текст, Саратов 2006, с. 31-111.

Франк С. Л., Духовное наследие Владимира Соловьева, «Вестник Русского Студенческого Христианского Движения» (1950) 4-5, с. 2-10.

Франк С. Л., Из писем М. О. Гершензону, «De visu» 3-4 (1994), с. 23-33.

Франк С. Л., Непостижимое. Онтологическое введение в философию религии, в: С. Л. Франк, Сочинения, Москва 1990, с. 183-559.

Франк С. Л., О задачах познания Пушкина, в: С. Л. Франк, Этюды о Пушкине, Paris 1987, c. 58-92.

Франк С. Л., Очерки философии культуры, в: С. Л. Франк, Непрочитанное... Статьи, письма, воспоминания, Москва 2001, с. 37-62.

Франк С. Л., Письмо к Г. Федотову от 27 июня 1949 г., публ. В. К. Кантора, «Вопросы философии» (2006) 3, с. 140-143.

Франк С. Л., Пушкин как политический мыслитель, в: С. Л. Франк, Этюды о Пуикине, Paris 1987, с. 28-57.

Франк С. Л., Пушкин об отночениях между Россией и Европой, в: С. Л. Франк, Этюды о Пушкине, Paris 1987, с. 93-107. 
Франк С. Л., Религиозность Пушкина, в: С. Л. Франк, Этюды о Пушкине, Paris 1987, c. 9-27.

Франк С. Л., Русская философия, ее характерная особенность и задача, в: С. Л. Франк, Русское мировоззрение, Санкт-Петербург 1996, с. 205-210.

Франк С. Л., Светлая печаль, в: С. Л. Франк, Этюды о Пушкине, Paris 1987, с. 108-127. Франк С. Л., Сущность и ведущие мотивы русской философии, в: С. Л. Франк, Русское мировоззрение, Санкт-Петербург 1996, с. 149-160.

Франк С., <Тетрадь с выписками - отчасти из немецких книг. Литература по истории мысли>, S. L. Frank Papers, Box 15, Bakhmeteff Archive, Rare Book and Manuscript Library, Columbia University.

Франк С. Л., Фр. Ницие и этика «любви к дальнему», в: С. Л. Франк, Сочинения, Москва 1990, с. 6-64.

Чаадаев П. Я., Сочинения и письма, ред. М. Гершензон, т. 1, Москва 1913.

Янцен В., Письма русских мьслителей в архиве Фрица Либа, в: Исследования по истории русской мысли. Ежегодник за 2001-2002 год, ред. М. А. Колеров, Москва 2002, с. 227-563.

Янцен В. В., Об иррациональном в истории. Биографические заметки к переписке С. Л. Франка и Д. И. Чижевского (1932-1937, 1947 г2.), в: Русский Берлин 19201945, ред. М. А. Васильева, Л. С. Флейшман, Москва 2006, с. 304-326.

Chronik russischen Lebens in Deutschland 1918-1941, Hrsg. K. Schlögel и др., Berlin 1999. Frank S., Contemporary Russian Philosophy, «The Monist» 1 (1927), c. 1-23.

Frank S., [Рецензия на:] Winkler Martin. Peter Jacovlevič Čaadaev, «Kant-Studien» 35 (1930) 2/3, c. 388-389.

Tschaadajew P. J., Schriften und Briefe, Übersetzt und eingeleitet von E. Hurwicz, D. Masken, München 1921. 